\title{
Innovative Teaching Methodology: Application of Computer and Technology in Iranian Business English Courses
}

\author{
Farnaz Latif \\ Department of Foreign Languages, Khorasgan Branch, Islamic Azad University, Isfahan, Iran \\ Email: Farnaz.latif@gmail.com \\ Mahdieh Shafipoor \\ Department of English Language Translation, Shahr-e-Qods Branch, Islamic Azad University, Tehran, Iran \\ Email: m.shafipoor@yahoo.com
}

\begin{abstract}
Business English teachers ought to look for simple, enthusiastic and learner friendly ways to facilitate teaching while drawing the attention of their eager learners who are expecting specific target achievements. As it is stated by Kern and Warschauer (2000), in line with this requirement and expectation the development of Computer assisted language learning around the globe and its impacts on language pedagogy, Computer assisted language learning in general and application of technology in particular can assist Business English teachers to provide the learners with an intriguing and stimulating atmosphere to learn business Skills. The aim of this paper is to report a pilot study on the adoption of technology in SAPCO business English classes for a two- year long period and mainly reflect the 733 learners' feedback over teachers' performance in these classes. It should be mentioned that this study is an ongoing study which will have several phases focusing on assessment, peer-observation, team-teaching and e-learning that will be elaborated on the forthcoming papers.
\end{abstract}

Index Terms - CALL (Computer assisted language learning), technology, business English, e-learning, team teaching, assessment, peer-observation

\section{INTRODUCTION}

For the past several decades, the value of pedagogical implications of computers in classrooms has been controversially debated and explored in relevant scholarly investigations. According to Davis (2006), the reported evidence on the "heightened motivation of learners" through the application of computers as a learning facilitator device indicates a triumphant success for the application of means of technology in Education. However, the existing reflections in the history reveal simple and limited application of technology by instructors. In other words, majority of the instructors tend to employ technology as confined to simple writing assignments and surfing the net (Cuban, 2001; MacDonald, 2004; Oppenheimer, 1997, 2003). In this study, innovative application of CALL (computer assisted language learning) along with implication of means of technology in Business English classrooms in Iran is presented.

\section{A. History}

The history of pedagogical application of computers for language instruction purposes goes back to 1960s when it was initially introduced on university mainframe computers. Marty (1981) pointed out that the PLATO project, launched at the University of Illinois in 1960, was a momentous landmark in the early development of CALL. The advent of the microcomputer in the late 1970s drew the attention of a wider range of audience, ending up a boom in the development of CALL programs and a flurry of publications of books on CALL in the early 1980s.

There have been several attempts to document the history of CALL. Sander (1995) covers the period from the mid1960s to the mid-1990s, focusing on CALL in North America. Delcloque (2000) documents the history of CALL worldwide, from its commence in the 1960s to the advent of the new millennium. Davies (2005) reviews CALL's past and attempts to predict where it is heading to. Hubbard (2009) presents a compilation of 74 key articles and book excerpts, originally published in the years 1988-2007 that offers a comprehensive overview of the wide range of leading ideas and research results that have impetus impact on the development of CALL or that show promise in doing so in the future.

During the 1980s and 1990s several attempts were made to establish a CALL typology. A wide range of various types of CALL programs was classified by Davies \& Higgins (1985), Jones \& Fortescue (1987), Hardisty \& Windeatt (1989) . These entailed gap-filling and Cloze programs, multiple-choice programs, free-format (text-entry) programs, adventures and simulations, action mazes, sentence-reordering programs, exploratory programs - and "total Cloze", a 
type of program in which the learner has to reconstruct a whole text. Most of these early programs still exist in modernized versions.

Davies et al.(2011) state that since 1990s it has become increasingly difficult to categorize CALL as it now extends to the use of blogs, wikis, social networking, podcasting, Web 2.0 applications, language learning in virtual worlds and interactive whiteboards (Section 3.7).

Warschauer (1996) and Warschauer \& Healey (1998) took a different approach. Rather than focusing on the typology of CALL, they identified three general historical phases of CALL, classified according to their underlying pedagogical and methodological approaches:

The first phase embarked since 1950s and implemented officially during 1960s. This phase was fundamentally constructed on the basis of behaviorist theories of learning and teaching while concentrating on the importance of spoken forms over the written one with specific focus on drill and practice- based programs. Computers played tutorial role and acted as tutors for language instructions. This approach was mainly at work for vocabulary acquisition till 1970s that it lost its popularity as a result of the paradigm shifts in language teaching and invention of microcomputers. However, as mentioned by Bangs and Cantos (2006), the initial popularity of CALL came to an end due to two main reasons:

1. Lack of imagination and creativity in designing new and challenging exercises, and

2. The high cost and maintenance of the computers.

With the advent of cognitive school of thought and shifting attentions toward cognitive aspects of language, learning and in fact language was viewed as a mentally constructed system and Language learning is perceived to develop through the operation of innate cognitive ability or language input. Thus, language education was formed and led toward cognitive process involved in learning and use of language. It was when the second phase, communicative phase, emerged. This was considered as a theoretical and pedagogical reaction toward the behaviorist approach. Formfocused instruction and implicit grammar instruction were at priority. Learning was stressed to be a creative process of discovery, expression, and development in accordance with the cognitive theories. Programs such as text reconstruction software which allowed learners working alone or in groups to rearrange words and texts to discover patterns of language and meaning and simulations which stimulated discussion and discovery among learners working in pairs or groups were designed.

TABLE1.

THREE PHASES OF CALL

\begin{tabular}{|c|c|c|c|c|c|}
\hline Stage & Technology & Pedao & glage & & \\
\hline $\begin{array}{l}\text { 1960s-1980s: } \\
\text { Behavioristic or } \\
\text { structural CALL }\end{array}$ & Mainframe & $\begin{array}{l}\text { Grammar-translation and } \\
\text { Audio-Lingual }\end{array}$ & Structural & $\begin{array}{l}\text { Habit formation: } \\
\text { Repetitive drills } \\
\text { Drill-and-practice } \\
\text { Translations tests }\end{array}$ & $\begin{array}{l}\text { Sole source of } \\
\text { language } \\
\text { information to } \\
\text { give instruction }\end{array}$ \\
\hline $\begin{array}{l}\text { 1980s-1990s: } \\
\text { Communicative } \\
\text { CALL }\end{array}$ & PCs & $\begin{array}{l}\text { Communicative language } \\
\text { teaching }\end{array}$ & Cognitive & $\begin{array}{l}\text { Communicative exercises: } \\
\text { Using forms } \\
\text { Implicit grammar teaching } \\
\text { forms } \\
\text { Text reconstructions } \\
\text { Simulations }\end{array}$ & $\begin{array}{l}\text { Activator } \\
\text { Facilitator }\end{array}$ \\
\hline $\begin{array}{l}1900 \text { s to } 21^{\text {st }} \\
\text { century } \\
\text { Integrative } \\
\text { CALL }\end{array}$ & $\begin{array}{l}\text { Multimedia } \\
\text { Internet-based } \\
\text { application }\end{array}$ & $\begin{array}{l}\text { Content-Based, Task- } \\
\text { Based, Project-based, } \\
\text { ESP,EAP }\end{array}$ & $\begin{array}{l}\text { Social, socio- } \\
\text { cognitive }\end{array}$ & $\begin{array}{l}\text { Authentic social, context, } \\
\text { discourses } \\
\text { Integrate various skills(Reading, } \\
\text { Writing, listening, speaking) of } \\
\text { language learning and use }\end{array}$ & $\begin{array}{l}\text { Counselor } \\
\text { Mentor }\end{array}$ \\
\hline
\end{tabular}

Underwood (1984) applied the principles of communicative language teaching to CALL and established a number of premises for "Communicative CALL" (pp. 52-54):

1. Activities will focus on acquisition practice (using forms to communicate) rather than learning practice (forms them).

2. Grammar will always be implicit (built into the lesson or activity), though explicit grammar explanation will be available on a call-up basis.

3. Activities should require learners to take a creative action in the target language (or to produce a response based on comprehension of an utterance) rather than manipulating prefabricated language.

4. Activity feedback will not aim at correcting or evaluating each response: According to Terrell (1977), activity feedback will "raise expectations for competence in communication, and lower expectations for structural accuracy" ( $\mathrm{p}$. 325).

5. Activity feedback will avoid calling out learners' incorrect answers just as "wrong": Provide help by means of appropriate and well-formed models or give hints.

6. Activities and instructions should be written in the target language. CALL software should try to communicate with the learner without reverting to the learner's mother tongue, though some help or explanations can be made available on a call-up basis.

7. CALL activities should be flexible, not based on the principle that every stimulus has one and only one response. 
8. CALL activities should allow learners to explore the subject matter: there is no predetermined material of any sort, but rather an environment in which discoveries can be made.

9. CALL activities should create a context in which using the target language feels natural (on screen: learner(s)machine interaction and off-screen: learner(s) - learner(s)/teacher-learner(s) interaction).

10. CALL software is not an electronic book (CALL activities will aim at doing things books cannot).

11. CALL software should be fun and attractive (try to avoid drill exercises or exams).

Mayor (2001) contends that the above principles may have been drawn up some twenty years ago, but in their essence they remain sound, even though research has built on them through the years of experience, and not just in language learning.

With all the popularity, communicative CALL was criticized by constructivists. They stressed on the important impact of the past experience on learning. Therefore, they viewed learners as involved in meaning construction and mainly focused on what learners can analyze, investigate, collaborate, share, build and generate based on what they already know, rather than what facts, skills, and processes they can parrot. In fact they hold that learners are constructors rather than mere receivers of preached input. In other words, constructivist learning is based on learner's active participation in problem-solving and critical thinking in learning activities. As a result, many teachers moved away from a cognitive view of communicative teaching and placed greater emphasis on language in authentic social contexts. Task-based, project-based, and content-based approaches all sought to integrate learners in authentic environments, and also to integrate the various skills of language learning and use. This led to a new perspective on technology, language learning and teaching, which has been termed as integrative CALL, an approach which seeks both to integrate various skills, for example, listening, speaking, reading and writing, and also integrates technology more fully into the language learning and teaching process. According to Warschauer (1996), this phase is based on two technological developments of the last decade- multimedia computers and Internet. Warschauer adds that the multimedia technology represented by the CD-ROM allows the combination of various media such as sound, graphic, text and video on no one machine which facilitates integration of all four language skills.

With the increasing use of computers in areas like business, communication, and entertainment, educational instructions have also started examining ways to incorporate computers in the classroom. Since the appearance of language laboratories, technology has always been regarded as a new remedial aid for language teaching and learning. Nearly forty years ago, the latest technology gadget was the language laboratory, not the computer.

\section{B. The Benefits of CALL}

According to Wang (2006), pedagogical application of computer in language teaching entails the following merits;

- Fostering classroom learning: Application of technology in language classrooms can motivate learners and let them experience authentic moments in the classroom. This is carried out by means of audio-visual aids run by computer programs. In other words, this trend can foster and facilitate learning through simulating abstract issues concretely.

- Encouraging more individualized and autonomous learning: Learners often attend language classes with different needs, interests and heterogeneous levels of proficiency. These can not only act as pedagogical hindrances for the instructors but also can affect the learners' pace and style of learning. Technology and computers in particular can help teachers to meet the learners' needs with different educational aids at their own pace. This creates a learner-centered classroom environment where the instructors act as facilitators who give the learners opportunity to learn how to learn. With the help of individualized instruction, consequently, equal opportunities are provided for all kinds of learners, i.e. slower learners can catch up, and advanced learners can do extra assignments.

- Exchanging the stored data and resources: Through application of modern technology, classroom data are generated, stored, shared and swapped among learners and instructors.

- Facilitating communication through internet: Instructors and learners can swap data and information via internet and particularly through electronic mails. Moreover, through virtual resources like virtual libraries learners have more opportunity to explore and keep their knowledge updated while having exposure to the target language.

\section{Computer Assisted Language Learning within the Framework of Task Based Learning (TBL)}

The Task Based Learning (TBL) which has a great number of advocates around the globe was presented as a result of a paradigm shift in language from the behaviouristic PPP paradigm (present, practice and produce) into a learnercentered approach- the TBL paradigm. The traditional PPP approached language instruction as a rather rigid, teacher centered process where the instructor worked within a framework in accordance with the taught forms. In other words, the learners' performances were evaluated as correct or incorrect with reference to the specific taught forms and nothing outside the instructed forms was approved as correct response. TBL paradigm, on the other hand, provides the opportunity for an individual internal learning process, i.e. the learners carry out different tasks and interact with other peers in pairs or groups in order to create a more comfortable and anxiety- free atmosphere in the classroom. This is usually facilitated through instructors' support to supply appropriate tasks and material for the learners, instructors' counsellorship, observation and mentoring, employing continuous assessment, encouraging consciousness raising among the learners, facilitating clarification when needed, a catalyst for a language focus process. Thus, CALL (computer assisted language learning) can be innovatively practiced if integrated within the framework of TBL (task based Learning). CALL offers the language instructor and learner a number of activities and tasks that when carefully 
planned as part of the pedagogical room will facilitate language learning. Adventure games, Chat online, Cloze exercises, Commenting/correcting electronic texts/essays/exercises, Cross Words, Drills, "Electronic dictionaries, Electronic Portfolios, Fill-in the blank, Find the answers ,Find the right sequence (or jumbled sentences), Grammar, Hot words, Listening exercises, Matching words, sentences, or pictures, Multiple Choice, Role plays , Simulations, Task based learning and Vocabulary training are among many applications which can practically prove such an integration.

\section{The PILOT STUDY}

\section{A. Situation Analysis}

Effective Business skills courses were designed with request of an automotive part supplier company's (SAPCO) training department whose objective was upgrading staff English proficiency in accordance with their professional needs. As a result of SAPCO language committee meetings held in 1385, a need analysis matrix was drawn up indicating the staff's need in accordance with their organizational position in the company. At last, it was decided to hold classes for three groups of Experts, bosses and managers. Since this department had experienced General English training courses with "New Interchange" and "Passages", the first population of the students who were selected to participate in "Oxford Effective Business Skills" was among the Intermediate level students of New Interchange courses. Two major points were considered here;

1. learners' proficiency level ( Intermediate and upper-intermediate)

2. learners' organizational positions( Experts, bosses and managers)

\section{B. Course Description}

Effective business English classes were held in three courses namely; "Effective socializing", "Effective telephoning" and "Effective meetings". However, after two years and based on the organizational needs, a follow series of e-learning classes are being held that are accompanied with team-taught workshop courses that will be presented on the forth coming paper. The books are selected from Oxford publication business English series. The following tables illustrate the course specifications;

TABLE2.

FIRST SERIES OF CLASSES

\begin{tabular}{|l|l|l|l|l|l|}
\hline Course & Hours & Units & Started & Finished & Number of Classes held \\
\hline Effective socializing & 40 & 8 & $85 / 8 / 13$ & $85 / 10 / 25$ & 10 \\
\hline Effective telephoning & 60 & 10 & $86 / 1 / 18$ & $86 / 4 / 30$ & 10 \\
\hline Effective meeting & 40 & 8 & $86 / 7 / 29$ & $86 / 10 / 18$ & 7 \\
\hline
\end{tabular}

Note: Classes were held twice per week and each session lasted 1:30 minutes.

Number of female learners: 39

Number of male learners: 288

TABLE3.

SECOND SERIES OF CLASSES

\begin{tabular}{|l|l|l|l|l|l|}
\hline Course & Hours & Units & Started & Finished & Number of Classes held \\
\hline Effective socializing & 40 & 8 & $86 / 1 / 18$ & $86 / 3 / 21$ & 6 \\
\hline Effective telephoning & 60 & 10 & $86 / 10 / 22$ & $86 / 7 / 28$ & 5 \\
\hline Effective meetings & 40 & 8 & $87 / 1 / 9$ & $87 / 4 / 15$ & 3 \\
\hline
\end{tabular}

Note: Classes were held twice per week and each session lasted 1:30 minutes.

Number of female learners: 28

Number of male learners: 141

TABLE4.

THIRD SERIES OF CLASSES

\begin{tabular}{|l|l|l|l|l|l|}
\hline Course & Hours & Units & Started & Finished & Number of Classes held \\
\hline Effective socializing & 40 & 8 & $86 / 8 / 12$ & $86 / 10 / 17$ & 8 \\
\hline Effective telephoning & 60 & 10 & $87 / 8 / 6$ & Not finished & 5 \\
\hline Effective meetings & 40 & 8 & $87 / 86$ & Not finished & 2 \\
\hline
\end{tabular}

Note: Classes were held twice per week and each session lasted 1:30 minutes.

Number of female learners: 36

Number of male learners: 178

\section{Teachers' Performance Assessment}

Below you can find learners' average scores of the teachers' performance assessments done by learners through intranet. The assessments conducted end of every course. 
TABLE5.

TEACHERS'PERFORMANCE ASSESSMENT RESULTS

\begin{tabular}{|l|l|l|l|}
\hline & Effective socializing & Effective telephoning & Effective meeting \\
\hline First series & $\% 89.5$ & $\% 91$ & $\% 92$ \\
\hline Second series & $\% 94$ & $\% 95$ & $\% 92$ \\
\hline Third series & $\% 92$ & Not assessed yet & Not assessed yet \\
\hline
\end{tabular}

\section{Application of Technology in SAPCO Business English Classes}

Internet and Intranet: a web site was designed for the English courses in which there were supplementary links provided for the learners who could have access to them via intranet (in the company) and internet (outside the company). Furthermore, the classes were connected to the high- speed internet so that the teachers could have access to online educational sources.

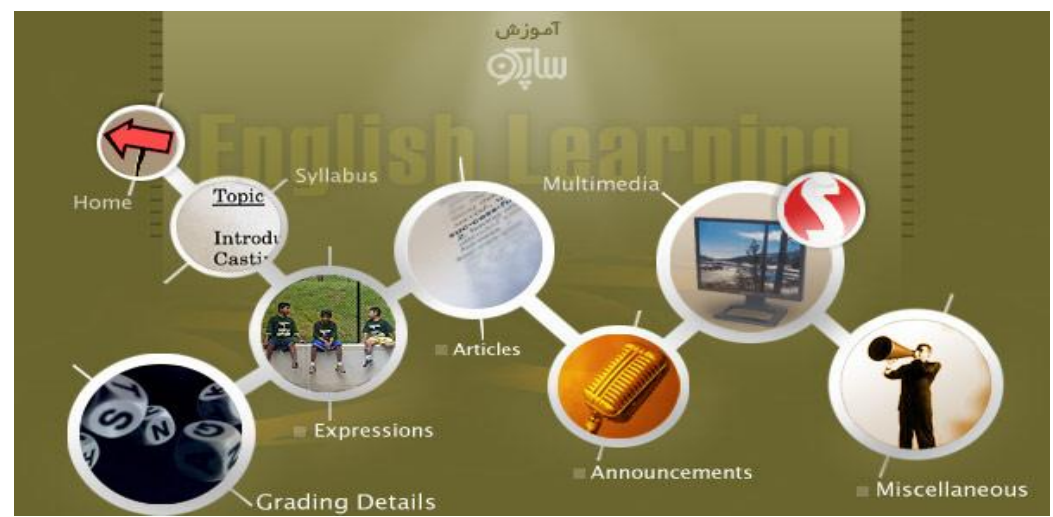

E-mail: teachers and learners swapped files including the "class notes", "assignments" and "tests". Teachers also provided the learners' with appropriate responses to their questions.

Computer video projector: each class was equipped with a video projector and a screen to act as a white board with the compatibility of storing data written on the board and simultaneous application of audio-video files in the classroom. The possibility to make use of various writing styles, stationeries and fonts by the teacher on the board added up to the learners' motivation in the class.

DVD player: The possibility to show films with optional subtitles and the ease of scene selection and of course the high quality of the films were of other advantages of DVDs that were replaced by VCDs and VHS cassettes.

Electronic Dictionary: Longman contemporary dictionary was installed in every class and teachers and learners could have access to definitions, examples and British/American pronunciation samples.

Mp3 player: teachers recorded the learners' voice in production phase then the audio files were mailed to them to have self-assessment and evaluate the individual progress by comparing their audio files during the course.

\section{E. Learners' Profile}

Learners who participated in these courses were mainly BA, BS, MA, MS graduates and a few were AA holders. Of total number of 733 participants $\% 86$ were male and $\% 14$ female learners. They majored in wide variety of engineering courses and were $\% 38 \mathrm{MS} / \mathrm{MA}, \% 60 \mathrm{BS} / \mathrm{BA}$ and $\% 2 \mathrm{AA}$ graduate students in engineering courses from public universities in Iran. The pre-requisite level was intermediate, so the first group was selected among the learners who had already passed Intermediate courses in SAPCO training department. The following series of classes were held after administrating Cambridge placement Test in SAPCO. Learners all were capable of using computer and Internet.

\section{F. Teachers' Profile}

Three female teachers with at least 10 years of experience participated in this project. The teachers held regular meetings to exchange experiences. They further kept journals and reflected their ideas on them. Teachers had basic knowledge of computer. They had already passed Windows, word, and Internet courses.

\section{FINAL WORDS}

The Business English courses designed in SAPCO are the first domestic system that is run with the application of CALL in the country. Thus, this can be viewed as the first experience for the training department administrators, teachers and learners. To evaluate the progress and the possible pinpoints, the teachers kept reflective journal writing as well as regular meetings. As indicated in teachers' performance progress table (questionnaires available on the intranet of SAPCO), learners considered their performance as developing through series of courses held. However, Learners' further feedback is illustrated in the following list:

1. Application of video projectors in the class motivated us more. 
2. The class-note saving and sending system is beneficial since we can have access to all the teacher's classroom notes via e-mail.

3. The possibility to ask questions and solve our language problems via e-mail outside the classroom is great.

4. The quality of DVDs are higher than VHS and that helps us in listening comprehension

5. Using electronic Longman contemporary Dictionary is fantastic. We can have access to the British and American pronunciations, collocations, and variety of definitions along with real example on the spot.

6. Teachers' use of PowerPoint presentation was so intriguing.

7. Classroom tasks were more effective.

8. Group work and pair works while looking at the screen instead of opening our books were interesting.

Regardless of the advantages, we should refer to possible drawbacks;

1. Both teachers and learners need to be trained how to work with computer and they need to have worked on basic ICDL skills.

2. The system will cost a lot for institutes. Although computers are available almost everywhere, video projectors and particularly their maintenance are costly.

3. High-speed internet connections are problematic in our country.

4. Since teachers are not paid for their outside class services provided for the students, they won't have enough motivation to mail the learners, work on word files, create PowerPoint and etc.

Forth coming phases

As mentioned earlier, this is an ongoing study and more findings regarding assessment, peer observation, team teaching and e-learning are under process and will be presented in the forthcoming papers.

\section{REFERENCES}

[1] Bangs, P \& Cantos, P (2004). IJES 4.1, 221-239.

[2] Cuban, L. (2001). Oversold and underused: Computers in the classroom. Cambridge. Mass: Harvard University Press.

[3] Davies G. \& Higgins J. (1982). Computers, language and language learning, London: CILT.

[4] Davies G. (1997). Lessons from the past, lessons for the future: 20 years of CALL. In Korsvold A-K. \& Rüschoff B. (eds.) New technologies in language learning and teaching, Strasbourg: Council of Europe.

[5] Davies G. (2005). Computer Assisted Language Learning: Where are we now and where are we going? http://www.camsoftpartners.co.uk/docs/UCALL_Keynote.htm.

[6] Davies G., Walker R., Rendall H. \& Hewer S. (2011). Introduction to Computer Assisted Language Learning (CALL). Module 1.4 in Davies G. (ed.) Information and Communications Technology for Language Teachers (ICT4LT), Slough, Thames Valley University.http://www.ict4lt.org/en/en_mod1-4.htm.

[7] Delcloque P. (2000). History of CALL. http://www.ict4lt.org/en/History_of_CALL.pdf

[8] Hardisty D. \& Windeatt S. (1989). CALL. Oxford: Oxford University Press.

[9] Hubbard P. (2009). (ed.) Computer-assisted language learning. Volumes I-IV, Routledge: London and New York: http://www.stanford.edu/ efs/callcc/

[10] Jacobs, GC, Milton, J \& Konstantinidis, G (1995). Autohall. Athens: Exodus

[11] Jones C. \& Fortescue S. (1987). Using computers in the language classroom .Harlow: Longman.

[12] Kern, R, \& Warschauer, M. (2000). Introduction: Theory and practice of network-based language teaching. In M. Warschauer \& R. Kern (Eds.), Network-based language teaching: Concepts and practice,1-19. Cambridge, England: Cambridge University Press.

[13] MacDonald, G. J. (2004). Contrarian finding: Computers are a drag on learning. (Retrieved May 26, 2006). http://www.csmonitor.com/2004/1206/p11s01-legn.html.

[14] Marty F. (1981). Reflections on the use of computers in second language acquisition. System 9, 2.85-98.

[15] Mayer, R. E. (2001). Multimedia learning. Cambridge, UK: Cambridge University Press.

[16] Milton, J (2001). Review of E Hanson- Smith (2000) Technology-Enhanced Learning Environments in System, 29(4). 525-27.

[17] Oppenheimer, T. (1997). The computer delusion. The Atlantic Monthly 280(1), 45-62.

[18] Oppenheimer, T. (2003). The flickering mind: The false promise of technology in the classroom and how learning can be saved. New York: Random House

[19] Sanders R. (ed.) (1995). Thirty years of computer-assisted language instruction, Festschrift for John R. Russell, CALICO Journal Special Issue, 12, 4.

[20] Terrell, T.D. (1977). A Natural Approach to Second Language Acquisition and Learning. Modern Language Journal.61. 32537.

[21] Underwood, J. (1984). Linguistics, computers, and the language teacher. Rowley, MA: Newbury House.

[22] Warschauer M. (1996). Computer-assisted language learning: an introduction. In Fotos S. (ed.) Multimedia language teaching, Tokyo: Logos International. http://www.ict4lt.org/en/warschauer.htm

[23] Warschauer M. \& Healey D. (1998). "Computers and language learning: an overview", Language Teaching 31: 57-71.

[24] Wang, X (2006). "Benefits and Drawbacks of Computer Assisted Language Teaching", Renmin University of China, 4.

Farnaz Latif is a PhD holder in TEFL who graduated from Department of Foreign Langauges, Khorasgan Branch, Islamic Azad University, Isfahan, Iran.At the moment, she is the head of language Department in Islamic Azad University Shahr-e- rey branch, and a General English Course instructor at university. In addition she is supervising and instructing Business English Courses in 
SAPCO ( an automative part supplier company).She has totally 14 years experience of teaching English in different fields. Her research interests are Teacher Education, ESP, CALL, Materials Development

Mahdieh Shafipoor is a TEFL M.A. holder and a faculty member at Islamic Azad University Shahr-e-Qods branch. She is a lecturer at research, testing, teaching methodology, and contrastive analysis. She also has totally 14 years' experience of teaching English in different fields. She has carried out research studies on applied linguistics. Her fields of interest are testing and assessment, syllabus design, and CALL. 